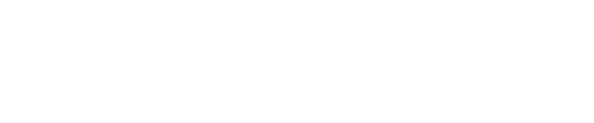

\title{
Assessment of heavy metal pollution in soil and their implications within and around mechanic villages
}

\author{
${ }^{1}$ M. A. Nwachukwu; ${ }^{1}$ H. Feng; ${ }^{2}$ J. Alinnor \\ ${ }^{1}$ Department of Earth and Environmental Studies, Montclair State University New Jersey, USA \\ ${ }^{2}$ Department of Chemistry, Federal University of Technology Owerri, Nigeria
}

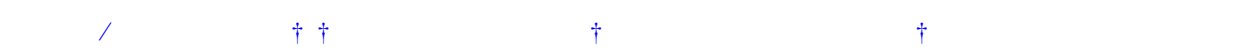

\begin{abstract}
Analysis of nine composite soil samples, each made of three replicate core samples and their respective background samples collected from Okigwe, Nekede and Orji automobile mechanic villages were conducted. Metal concentrations $(\mathrm{mg} / \mathrm{kg})$ above the background levels in the top $100 \mathrm{~cm}$ soil profile ranges as follows: 748-70,606 ( \pm 10114.3) for iron; $99-1090 \pm 251.3$ for lead; $186-600 \pm 180$ for manganese; $102-1001 \pm 201.9$ for copper; $8-23 \pm 12.9$ for cadmium; $4-27 \pm 6.0$ for chromium; and 3-10 \pm 2.2 for nickel. The order of abundance is: iron $>$ lead $>$ manganese $>$ copper $>$ cadmium $>$ chromium $>$ nickel, with Okigwe $>$ Nekede $>$ Orji. Pollution indexes show that the metals have similar pollution trends in the three layers $\left(\mathrm{L}_{1}-\mathrm{L}_{3}\right)$, with $\mathrm{L}_{1}(0-10 \mathrm{~cm})>\mathrm{L}_{2}(10-20 \mathrm{~cm})>\mathrm{L}_{3}(90-100 \mathrm{~cm})$ in Okigwe, $\mathrm{L}_{3}$ $>\mathrm{L}_{1}>\mathrm{L}_{2}$ in Nekede, and $\mathrm{L}_{3}>\mathrm{L}_{2}>\mathrm{L}_{1}$ in Orji. In effect, the shaly Okigwe soil is more polluted in the top layer while the sandy Nekede and Orji are more polluted in the lower layers. Despite this order, metal bioavailability may be less in the Okigwe soil due to its high clay-silt content (47\%-64\%). Pollution factor for Okigwe is 0.8 , Nekede is 0.7 and Orji is 0.5. Nekede is under severe to excessive pollution while Orji and Okigwe are under moderate to excessive pollution, with weathered depths $7.4 \mathrm{~m}$ at Orji and Nekede and $4 \mathrm{~m}$ at Okigwe as most implicated in the pollution process. Above provides the bases for introducing the innovative concepts of environmentally friendly mechanic village.
\end{abstract}

Keywords: Automobile wastes; Environmentally friendly mechanic village; Pollution factor; Pollution index

\section{INTRODUCTION}

A mechanic village is an area of open land allocated to automobile repair workers in the vicinity of an urban centre. A typical city usually has one to three mechanic villages, in proportion to its population and activities, but some cities have more. With the European and American automobile industries moving towards greener electric cars, the international trade on used motor vehicles is presumed to increase dramatically. As a result, great numbers of old fuel - guzzling cars of all models are expected to stream into the Atlantic coast of West Africa and largely to Nigeria and also to other developing countries in this first quarter of the century. Urban areas where the mechanic village concept is in practice will react to the increased supply by establishing more mechanic villages, whereas those not already practicing mechanic villages may buy the concept. This may amount to greater soil and other environmental pollution if the present poor waste management; the habit of spilling waste oil and other

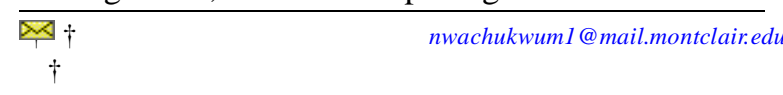

automobile wastes on the ground are allowed to continue. The primary objective of this study is to have an overview of the trend and level of heavy metal enrichment of soil in the three MVs after 28 years of its practice in the basin. This is a first step towards introducing the concept of environmentally friendly mechanic villages in the region and probably the first environmental pollution assessment of MVs in this direction. Great numbers of literature materials exist on anthropogenic dispersion and concentration of heavy metals in soil, including Remon et al., (2005); Xinming et al., (2005); Liu et al., (2007); Onweremadu and Duruigbo (2007). Heavy metals are considered serious pollutants because of toxicity, persistent and nondegradable conditions in the environment (Tam and Wong, 2000; Yuan et al., 2004; Nwuche and Ugoji, 2008; Aina et al., 2009; Mohiuddin et al., 2010). Extensive trace metal pollution of soil within and around MVs implies that water bodies (surface and groundwater) within and away from the vicinity of a MV may equally be polluted with trace metals due to continuous 
interactions between soil and water and high dispersion rate in the tropical rain forest belt. Virkutyte and Sillanpää (2006) and Huang et al. (2008 and 2009), have used trace metal analysis to determine water quality in east Qinghai and in the Tibetan Plateau, respectively. Toxicity of heavy metals to biota above certain threshold values have been discussed (David and Johanna, 2000; D’ Ascol et al., 2005; Feng et al., 2009). Dioka et al., (2004) investigated blood Pb-level among a group of students on one side and a group of automobile mechanics drafted from a mechanic village at Nnewi near the Imo River Basin. Results of their study showed high lead blood levels in the mechanics, due to their exposure to lead in Nigeria petrol. This increases the concentrations of uric acid (357 $\pm 123 \mu$ $\mathrm{mol} / \mathrm{L})$ and phosphate $(1.5 \pm 0.5 \mathrm{~m} \mathrm{~mol} / \mathrm{L})$, that may compromise liver and renal function.

Urban soil pollution can be assessed using pollution index (Pi). For example, Liu et al., (2007), obtained Pi as a ratio of metal concentration in a contaminated soil sample and its concentration in a natural background sample, whereas Diatta et al. (2003) obtained Pi as a ratio of the metal concentration in a contaminated soil sample and the local maximum allowable limit (MAL) value of the metal. Metal enrichment factor (EF) has been particularly used to assess metal enrichments in sediments of rivers and estuaries (Ergin et al., 1991; Feng et al., 1998, 2004; Zhang et al., 2007; Zhang et al.,

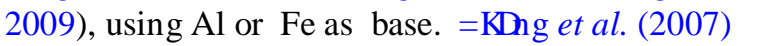
Karbassi et al (2008) also suggested the use of normal crustal values as base. According to Zang and Liu (2002), EF $>1.5$ suggests that a significant proportion of trace metals is delivered by anthropogenic activities (non-crustal materials). Hans et al., (2006) stated that

EF values $<2$ suggest minimal metal enrichment and values $>2$ suggest various degrees of metal enrichments. In data analysis using statistical predictions and comparisons, Mandel (1991), Crowder (1992) and Rukhin et al., (1998) have used mean and $\mathrm{Mu}$ values.

\section{Automobile wastes in mechanic villages}

In Nigeria, soil pollution problems associated with spilling of automobile wastes has been reported (Onianwa et al., 2001; Ipeaiyeda et al., 2008; Iwegbue 2007). It is commonly known that when an automobile is running, the engine oil, transmission oil and hydraulic fluid collect heavy metal debris containing $\mathrm{Pb}, \mathrm{Cd}, \mathrm{Zn}, \mathrm{Fe}, \mathrm{Cu}$, etc. due to frictional wears. The amount of frictional wear and tear, however, is expected to depend on the age and conditions of the engine and the transmission systems. Predominance of old motor vehicles and continuous engine and gear box recycling are responsible for the increased wear and tear or the concentration of heavy metals in the used oil. Iwegbue (2007) determined metal fractionation in soil profiles at an automobile mechanic village waste dump near Port-Harcourt close to the Imo River Basin and observed a mobility order: $\mathrm{Cd}>\mathrm{Zn}>\mathrm{Pb}>\mathrm{Cu}>\mathrm{Cr}>\mathrm{Ni}$. His findings would have been peculiar to the dump, following the type of automobile waste at the dump, volume of waste and length of time the dump has been in use. Usually an automobile waste dump will consist predominantly of auto body scraps (Al), pieces of mild steel (Fe), electrical components and wires $(\mathrm{Cu})$, short of other occupational wastes of mechanic villages as illustrated in Fig. 2.

\section{Description of the study area}

Geographically, the basin is a $140 \mathrm{~km} \mathrm{N-S}$ trending sedimentary syncline located at the mid south-eastern part of Nigeria (Fig. 1a). It has abundant deposit of clay minerals, sand, gravel, shale and lignite (Onyeagocha, 1980). The Orji mechanic village $\left(0.41 \mathrm{~km}^{2}\right)$ and the Nekede $\left(0.55 \mathrm{~km}^{2}\right)$ are located in the sandy Benin Formation while the Okigwe $\left(0.3 \mathrm{~km}^{2}\right)$ is located in the Imo shale group as shown in the geological map (Fig. 1c).

Fig. 1b shows the drainage network of major rivers in the basin and location of the mechanic villages. These rivers are predominantly the tributaries of the Imo River, which joins the Niger River that discharges into the Atlantic Ocean. The field work for this study was conducted between June and August 2009, about the peak of rain season when topsoil is predominantly wet, with fresh loading of metal contaminants at drainage collection points.

\section{MATERIALS AND METHODS}

Soil sampling techniques and analytical methods

Environmental quality assessment of soil can be made by various methods, based on the available data and the environmental conditions prevailing in the locality or region of study. Soil samples were randomly collected at drainage collection points along the direction of drainage in the respective mechanic villages, as illustrated in Fig. 3. Usually three sample 


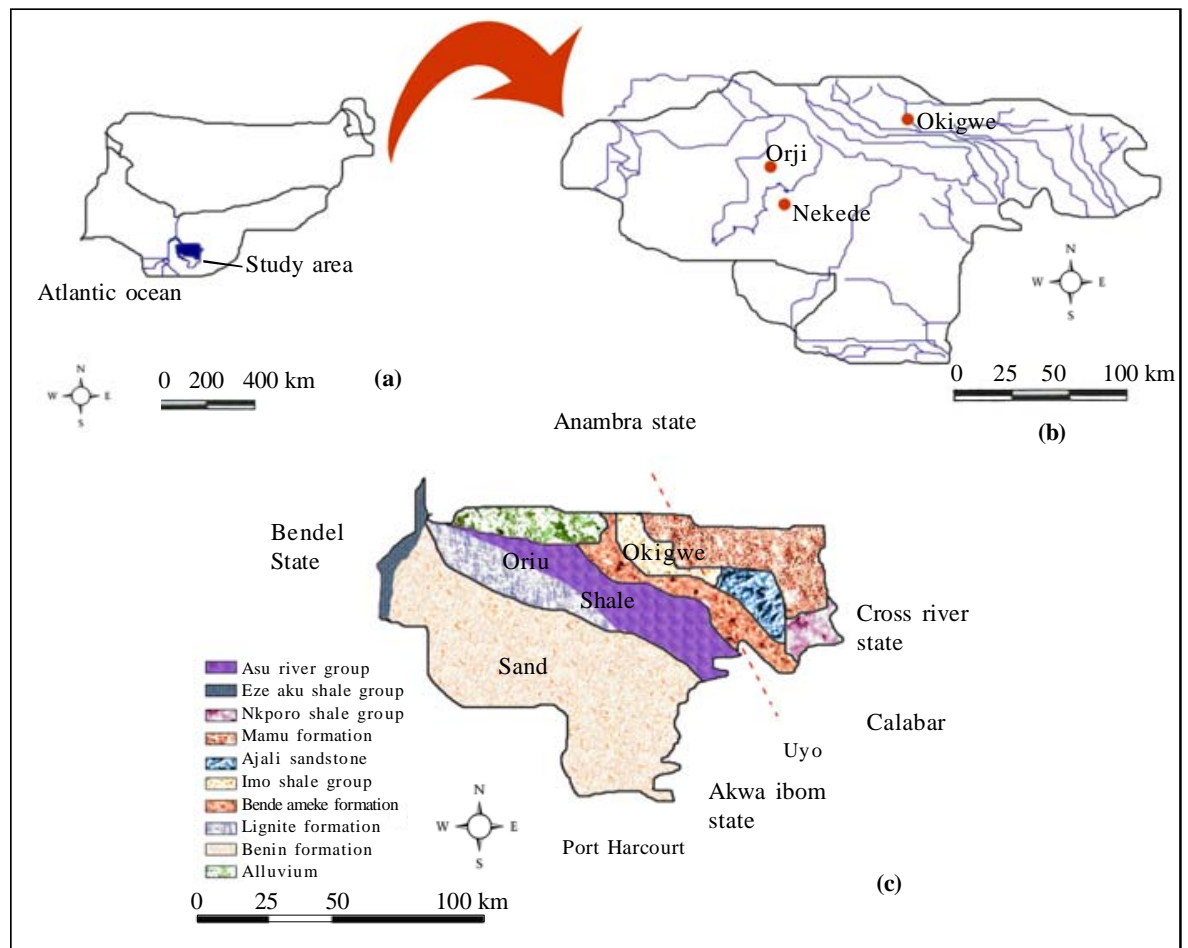

Fig. 1: a) Map of Nigeria locating the Imo River Basin, b) Drainage map of the Imo River Basin after Nuga et al., 2006 locating the three mechanic villages and c) Geologic map of the Imo River Basin after Onyeagocha (1980)

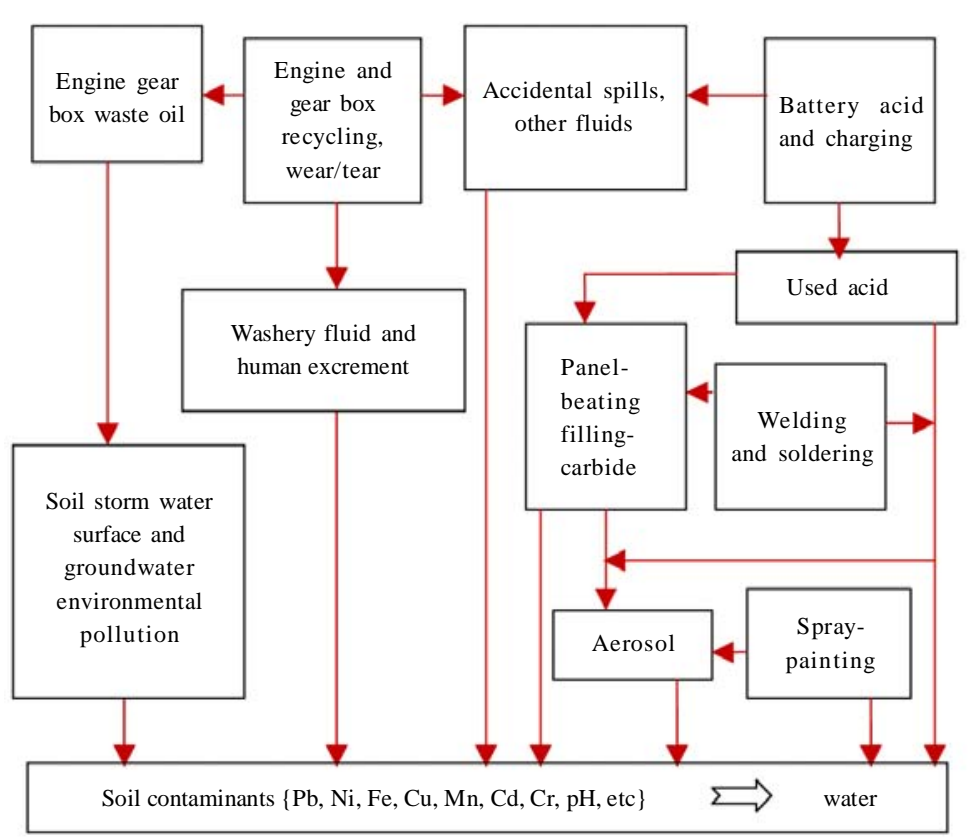

Fig. 2: A hypothetical model of the sources of occupational wastes causing soil pollution in mechanical villages 


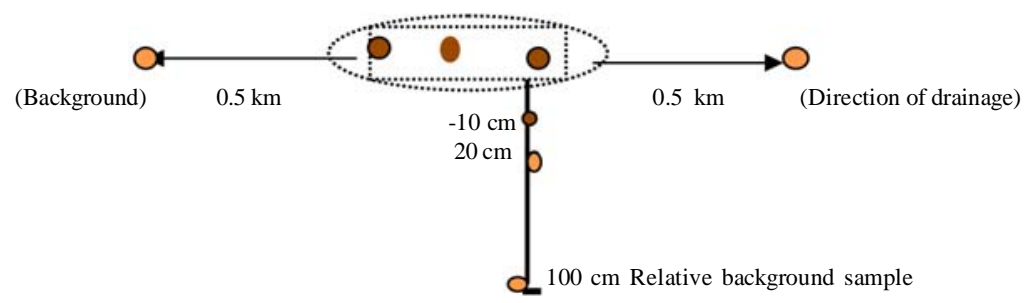

Fig. 3: Soil sampling points (field procedure)

locations were been identified within the drainage area of each mechanic village. At each location, samples were been collected at $10 \mathrm{~cm}, 20 \mathrm{~cm}$ and $100 \mathrm{~cm}$ depths. The three samples of each depth from the three locations were homogenised to make a composite sample of each depth. A background sample or the control similarly collected $500 \mathrm{~m}$ away from each mechanic village, against the direction of drainage. Samples were prepared and digested using 4-acid digestion method for total metal, in line with the USEPA (2007) 3050/305, as in EPA document SW-846. The SOLAAR UNICAM 969 atomic absorption spectrometer (AAS) was used for the metal analysis (Barabara et al., 2002; Pardo, 2002). Environmental quality assessment in this study has been based on a comparative analysis of metal concentration in the mechanic villages' soil and their respective background values, rather than base on the values of $\mathrm{Al}$ or Fe. $\mathrm{Al}$ and Fe being the most common crustal metals and their preferred use in automobile body suggests that the metals will be most widely abundant in a mechanic village soil. Possibility of metal complexes such as $\mathrm{Al}^{3+} / \mathrm{F}^{-}$(Corbillon et al., 2008) and metal/EDTA or DTPA Sorvari and Sillanpää (1996) may cause some difficulty when comparing trace metal enrichments in MV soils of different geologic environments using $\mathrm{Al}$ or Fe as reference metals.

\section{Pollution assessment criteria}

In this study, three different criteria were used for the pollution assessment: (1) Pollution index (Pi) per metal with significant pollution considered from $\mathrm{Pi}>1$. (2) A modelling technique based on the Gaussian process (JMP version 2007, Version 7. SAS Institute Inc; Cary, NC, 1989-2007) by plotting mg/kg metals' concentration above the background values as actual against their measured values in each of the mechanic villages as predicted (Fig. 6a-c). Ratio of mean Mu of metals concentration above the background values, with the mean of total metal concentration in the mechanic village obtained from model is used in this research as pollution factor $(P f)$. Statistical analysis is based on the following mathematically relations:

$P_{i}=\frac{C_{i}(m)}{C_{i}(b)}$

Where, $C i(m)$ is the concentration of the $\mathrm{i}^{\text {th }}$ pollutant in $\mathrm{mg} / \mathrm{kg}$ obtained in themechanic village. $C i(b)=$ Relative background concentration of $\mathrm{i}^{\text {th }}$ pollutant ( $\left.\mathrm{mg} / \mathrm{kg}\right)$,

$P_{f}=\frac{C_{i}(m)-C_{i}(b)}{C_{i}(m)}$ per metal $P_{f}=\frac{M U \text { of } M c-B c}{\text { Mean of } M c}$

per mechanic village

Where, Mu: is the value at which the distribution is symmetrical and equal with respect to mean, Mc: is the concentration of metals in the mechanic village, and Bc: is the concentration of metals in the background. Using the formula of the Dutch system (Lacatusu, 1998; Chee Poh, 2006), the distinction between soil contamination range and soil pollution range as established by contamination/pollution index $(\mathrm{Ci} / \mathrm{Pi})$, values higher than 1 defines the pollution range and those lower than 1 define the contamination range. Pollution range was divided into intervals that define: a slight (1.1- 2.0), moderate (2.1-4.0), severe (4.1-8.0), very severe (8.1-16.0) and excessive pollution (>16.0), respectively. In this study, the contamination/pollution index is used for pollution classification $(P C)$, and established per metal as follows:

$P C=\frac{C_{i}(m)-C_{i}(b)}{P_{i}}$

Ci (m) and Ci (b) are as previously explained.

\section{Physical tests}

Physical analysis was conducted on the composite soil samples of the two layers (0-20 cm and 20-100 cm profile layers). The composite samples were tested for grain size distribution, clay-silt content, moisture 
content, and $\mathrm{pH}$ and bulk density. Rate of infiltration was also measured in the field by the ASTM (D3385 2009) standard test methods for infiltration rate of soils using a double-ring infiltrometer.

\section{RESULTS AND DISCUSSIONS}

Analytical results

Table 1 represents a distribution of the seven investigated heavy metals indicating that the heavy metal concentrations in the top $100 \mathrm{~cm}$ of soil in the three mechanic villages are well above the local background values and have caused severe to excessive pollution capable of serious ecological and public health hazards. This implies that metal pollution levels in mechanic villages are not of natural geology or the processes of weathering and deposition. Though the threat posed by trace metals to human health and the environment is thought to be dependent on their speciation in the soil solution rather than the total concentration (Murray and Hendershot, 2000). For example, Igbozurike et al., (2009) tested cassava plant tubers (a most staple food product) harvested from an abandoned sewage sludge dump near Nekede and observed high heavy metal concentrations compared to their background levels. This is the type of future research most recommended in the vicinity of mechanic villages in order to advise the public on safe farming distance to mechanic villages in the contaminated soil. Similar test on vegetables and tubers cultivated within and around mechanic village direction of drainage is recommended in future studies. The pollution index variability analysis shows that metal pollution across the mechanic villages has significant spatial variation with respect to depths. Considering the average level shown on the chart as a local threshold for each mechanic village, the potentials of each metal for pollution can be observed from the range of pollution index mean value falling above the threshold value, which is more strictly defined by the standard deviation curve. The metals that have the highest pollution potentials are in the order of $\mathrm{Cu}>\mathrm{Cr}>\mathrm{Mn}>\mathrm{Pb}$ at Okigwe (Fig. 4a), $\mathrm{Cr}>\mathrm{Mn}>\mathrm{Cd}>\mathrm{Pb}>\mathrm{Cu}$ at Orji (Fig. 4b) and $\mathrm{Mn}>\mathrm{Cu}>\mathrm{Cr}>\mathrm{Pb}$ at Nekede (Fig. 4c). The metals with the most variable pollution potentials in the mechanic villages are $\mathrm{Mn}, \mathrm{Cr}, \mathrm{Pb}$ and $\mathrm{Cu}$. As a background metal, Fe is in excess and not included in this analysis to avoid distortion. The analysis shows

Table 1: Metal distribution and analysis in the $100 \mathrm{~cm}$ depths soil profile

\begin{tabular}{|c|c|c|c|c|c|c|c|c|c|c|c|c|}
\hline \multirow{2}{*}{$\begin{array}{l}\text { Metals } \\
\text { and Depths } \\
0-10 \mathrm{~cm} \text { layer }\end{array}$} & \multicolumn{3}{|c|}{ Background (mg/kg) } & \multicolumn{4}{|c|}{ Mechanic village (mg/kg) } & \multirow[b]{2}{*}{ Nekede } & \multirow[b]{2}{*}{$\mathrm{Pi}$} & \multirow{2}{*}{$\begin{array}{l}\text { PC } \\
\text { Okigwe }\end{array}$} & \multirow{2}{*}{$\begin{array}{l}\text { PC- } \\
\text { Nekede }\end{array}$} & \multirow{2}{*}{$\begin{array}{l}\text { PC- } \\
\text { Orji }\end{array}$} \\
\hline & Okigwe & Orji & Nekede & Okigwe & $\mathrm{Pi}$ & Orji & $\mathrm{Pi}$ & & & & & \\
\hline $\mathrm{Fe}$ & 50613 & 32151 & 14795 & 121219 & 2.4 & 42709 & 1.3 & 45289 & 3.1 & 29419 & 9836.8 & 8122 \\
\hline $\mathrm{Ni}$ & 21.5 & 14.5 & 11 & 24.7 & 1.2 & 24.8 & 0.8 & 18.3 & 1.7 & 2.7 & 4.3 & 12.9 \\
\hline $\mathrm{Cd}$ & 22.5 & 18.5 & 16.5 & 42.5 & 1.9 & 31.5 & 1.7 & 32.5 & 2 & 10.5 & 8 & 7.6 \\
\hline $\mathrm{Pb}$ & 469 & 359 & 309 & 1559 & 3.3 & 619 & 1.7 & 759 & $2 . \overline{5}$ & 330.3 & 180 & 152.9 \\
\hline $\mathrm{Cu}$ & 280 & 249 & 258 & 1281 & 4.6 & 571 & 2.3 & 569 & 2.2 & 217.6 & 141.3 & 140 \\
\hline $\mathrm{Cr}$ & 13.7 & 8.6 & 8.2 & 26 & 1.9 & 19.5 & 2.3 & 16.8 & 2.1 & 6.5 & 4.1 & 4.7 \\
\hline $\mathrm{Mn}$ & 471 & 341 & 374 & 817 & 1.7 & 696 & 2 & 627 & 1.7 & 203.5 & 148.8 & 177.5 \\
\hline \multicolumn{13}{|l|}{$10-20 \mathrm{~cm}$ layer } \\
\hline $\mathrm{Fe}$ & 73,187 & 40,077 & 52,025 & 121,857 & 1.7 & 40,825 & 1 & 69,681 & 1.3 & 28629 & 13581.5 & 748 \\
\hline $\mathrm{Ni}$ & 17.5 & 11.3 & 9.4 & 26.5 & 1.5 & 17.5 & 1.6 & 18.4 & 2 & 6 & 4.5 & 3.9 \\
\hline $\mathrm{Cd}$ & 24.5 & 15.5 & 17.5 & 47.5 & 1.9 & 38.5 & 2.5 & 26.5 & 1.5 & 12.1 & 6 & 9.2 \\
\hline $\mathrm{Pb}$ & 489 & 410 & 339 & 649 & 1.3 & 509 & 1.2 & 547 & 1.6 & 123 & 130 & 82.5 \\
\hline $\mathrm{Cu}$ & 295 & 289 & 273 & 561 & 1.9 & 442 & 1.5 & 375 & 1.4 & 140 & 72.9 & 102 \\
\hline $\mathrm{Cr}$ & 9.1 & 6.4 & 7.2 & 36 & 4 & 24 & 3.8 & 20 & 2.8 & 6.7 & 4.6 & 4.6 \\
\hline Mn & 364 & 272 & 250 & 553 & 1.5 & 458 & 1.7 & 478 & 1.9 & 126 & 120 & 109.4 \\
\hline \multicolumn{13}{|c|}{$90-100 \mathrm{~cm}$ layer } \\
\hline $\mathrm{Fe}$ & 80,045 & 14,225 & 27,927 & 114,641 & 1.4 & 20,595 & 1.5 & 46,079 & 1.7 & 24711 & 10577.6 & 4247 \\
\hline $\mathrm{Ni}$ & 14.5 & 9.5 & 10.5 & 24.5 & 1.7 & 16.5 & 1.7 & 18.5 & 1.8 & 5.9 & 4.4 & 4.1 \\
\hline $\mathrm{Cd}$ & 23.5 & 11.5 & 17.5 & 40.5 & 1.7 & 33.5 & 2.9 & 25.5 & 1.5 & 10 & 5.3 & 7.6 \\
\hline $\mathrm{Pb}$ & 409 & 189 & 279 & 659 & 1.6 & 520 & 2.8 & 580 & 2.1 & 156.3 & 143.3 & 118.2 \\
\hline $\mathrm{Cu}$ & 257 & 200 & 213 & 837 & 3.3 & 500 & 2.5 & 594 & 2.8 & 175.8 & 136.1 & 120 \\
\hline $\mathrm{Cr}$ & 28 & 20 & 18 & 38 & 1.4 & 24 & 1.2 & 28 & 1.6 & 7.1 & 6.3 & 3.3 \\
\hline $\mathrm{Mn}$ & 258 & 180 & 158 & 858 & 3.3 & 648 & 3.6 & 728 & 4.6 & 181.8 & 123.9 & 130 \\
\hline \multirow{2}{*}{\multicolumn{2}{|c|}{$\begin{array}{l}\text { Metals mean values } \\
\text { Okigwe M-B (mg/kg) }\end{array}$}} & \multicolumn{2}{|c|}{$\mathrm{Fe}$} & \multicolumn{2}{|c|}{$\mathrm{Pb}$} & \multicolumn{2}{|c|}{$\mathrm{Mn}$} & \multicolumn{2}{|c|}{$\mathrm{Cu}$} & $\mathrm{Cr}$ & $\mathrm{Cd}$ & $\mathrm{Ni}$ \\
\hline & & \multicolumn{2}{|c|}{$51290.7 \pm 18147$} & \multicolumn{2}{|c|}{$500 \pm 513$} & \multicolumn{2}{|c|}{$378.3 \pm 207$} & \multicolumn{2}{|c|}{$615.7 \pm 369$} & $16 \pm 9$ & $20 \pm 3$ & $22 \pm 4$ \\
\hline \multirow{2}{*}{\multicolumn{2}{|c|}{$\begin{array}{r}\text { Nekede M-B (mg/kg) } \\
\text { Orji M-B (mg/kg) }\end{array}$}} & \multicolumn{2}{|c|}{$22100.7 \pm 7273$} & \multicolumn{2}{|c|}{$319.7 \pm 122$} & \multicolumn{2}{|c|}{$350.3 \pm 191$} & \multicolumn{2}{|c|}{$264.7 \pm 145$} & $11 \pm 2$ & $11 \pm 4$ & $8 \pm 0.8$ \\
\hline & & \multicolumn{2}{|c|}{$5892 \pm 4922$} & \multicolumn{2}{|c|}{$230 \pm 119$} & \multicolumn{2}{|c|}{$336.3 \pm 142$} & \multicolumn{2}{|c|}{$258.3 \pm 92$} & $11 \pm 7$ & $19 \pm 6$ & $8 \pm 2$ \\
\hline
\end{tabular}

*M-B (Metal concentration in mechanic village (M) minus background value (B)) 

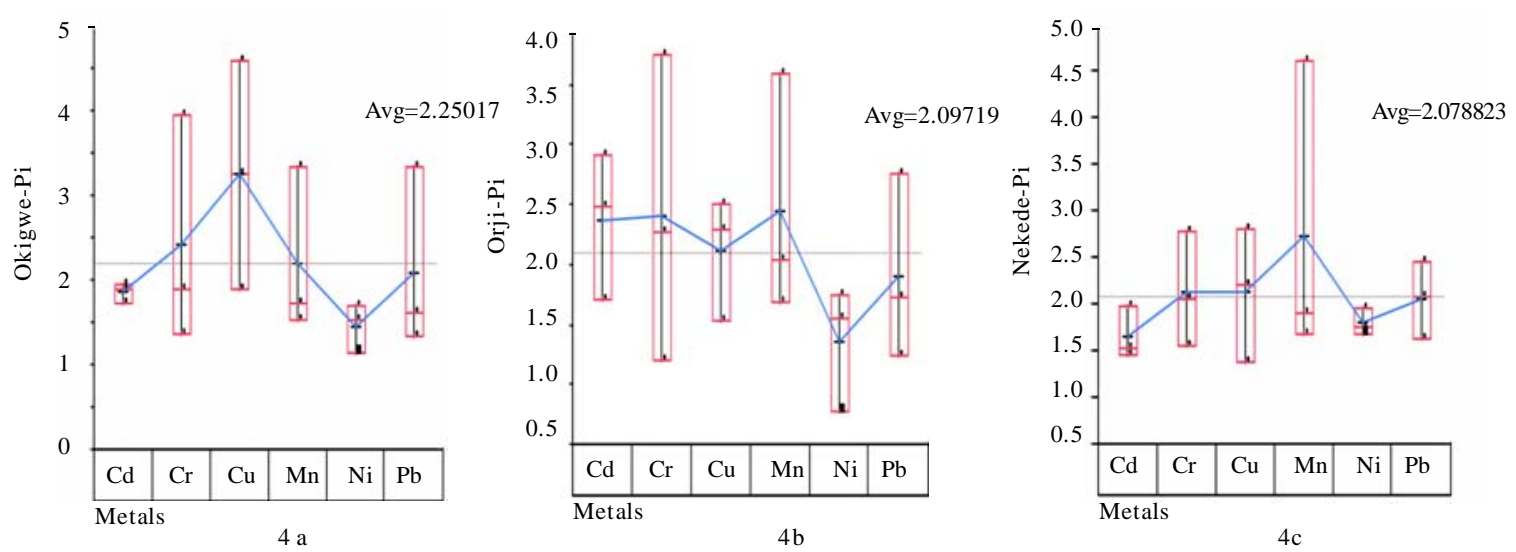

Fig. 4: Variability chart for Pi: Okigwe (4a),Orji (5b) and Nekede (4c). The connector line shows mean Pi per metal.
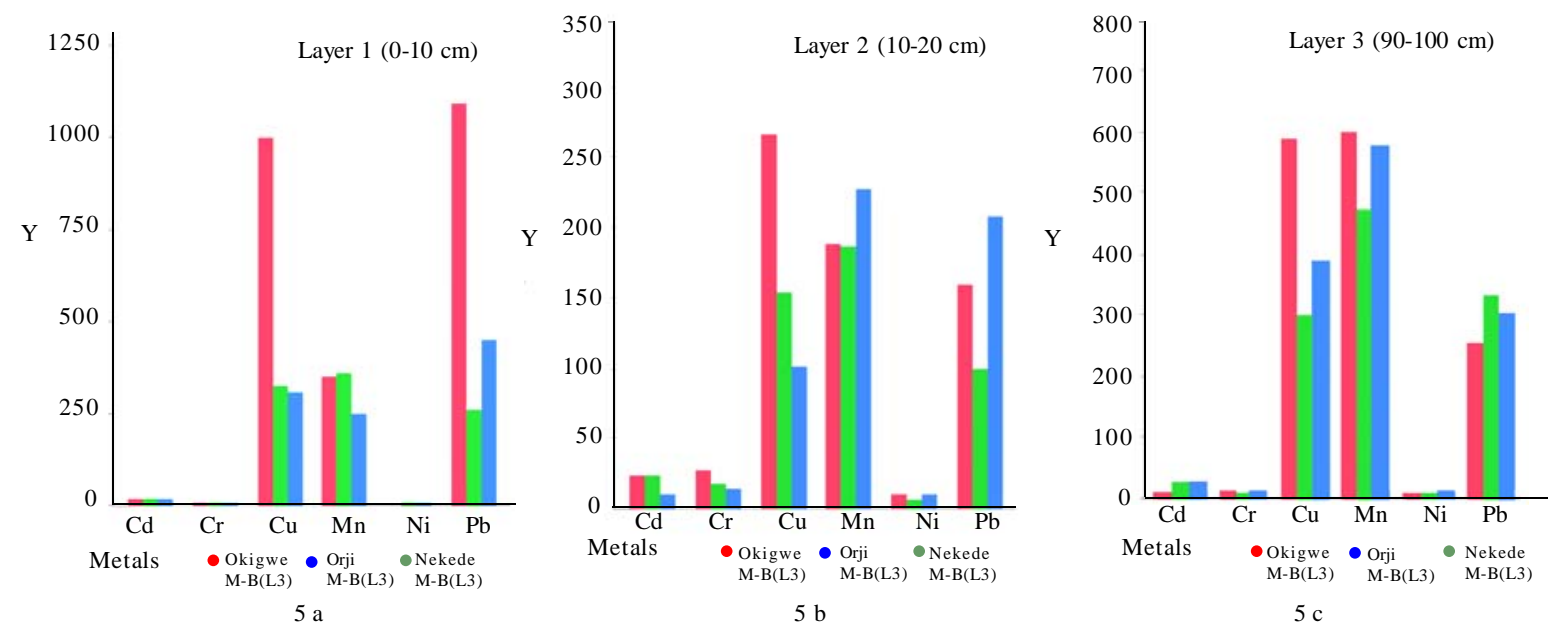

Fig. 5: Chart showing the distribution of metals in the three profile layers investigated

that metal concentrations in the Okigwe mechanic village most significantly deviate from the background or threshold values (Fig. 4a), indicating the highest pollution potentials in the area. Fig. 5a-c represents three charts showing spatial distribution of metals in the three layers: L1 (0-10 cm), L2 (10-20 cm), L3 (90-100 $\mathrm{cm}$ ) of the $100 \mathrm{~cm}$ soil profile for each of the mechanic villages. Metal distribution is as follows: Okigwe $\mathrm{Pb}$ : L1 > L3 > L2; Mn: L3 > L1 > L2; Cu: L1 > L3 > L2. Orji Pb: L3 > L1 > L2; Mn: L3 > L1 > L2; Cu: L3 > L1 > L2. Nekede Pb: L1 > L3 > L2; Mn: L3 > L2 >L1; Cu: L3 > L1 > L2. Others with lower concentration and less pollution potentials are: Cd: Okigwe same as Orji (layer 2); Cr: Okigwe $>$ Orji $>$ Nekede (layer 2). Fe: Okigwe $>$ Nekede $>$ Orji. Metal enrichments of the $100 \mathrm{~cm}$ soil profile were found to increase with depth of the layers in the sandy Orji and Nekede mechanic villages as against the order in the Okigwe mechanic village except for Mn (Fig. 7). Above models (Fig. 6a-c) based on the Gaussian process is used to obtain the Mu and mean values used in calculating the pollution factor for each mechanic village. Result indicate that the Okigwe mechanic village topsoil is the most polluted, having the highest pollution factor $(P f)$ of 0.8 , as a ratio of 344 and 449. This is followed closely by the Nekede mechanic village with a $P f$ of 0.7 as a ratio of 207 and 303 and the Orji mechanic village with a $P f$ of 0.5 as a ratio of 141 and 288. Analysis based on quantiles (25) shows greater abundance of $\mathrm{Pb}, \mathrm{Mn}$ and $\mathrm{Cu}$ in the three mechanic villages. These metals constitute the pollutants 

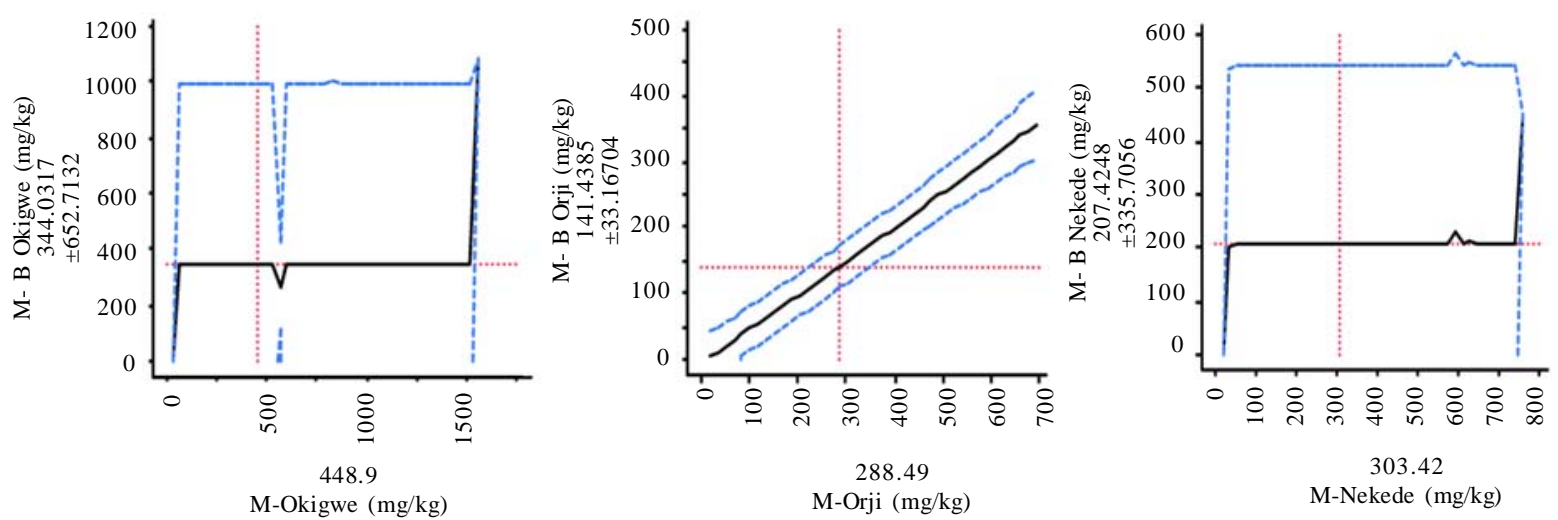

Fig. 6: Prediction profiling model of soil in the three mechanic villages (concentrations above background values modelled against total concentration. Okigwe: MU: 344.0, Av: 448.9; Orji: MU: 141.44, Av: 288.5; Nekede: MU: 207.4, Av: 303.4
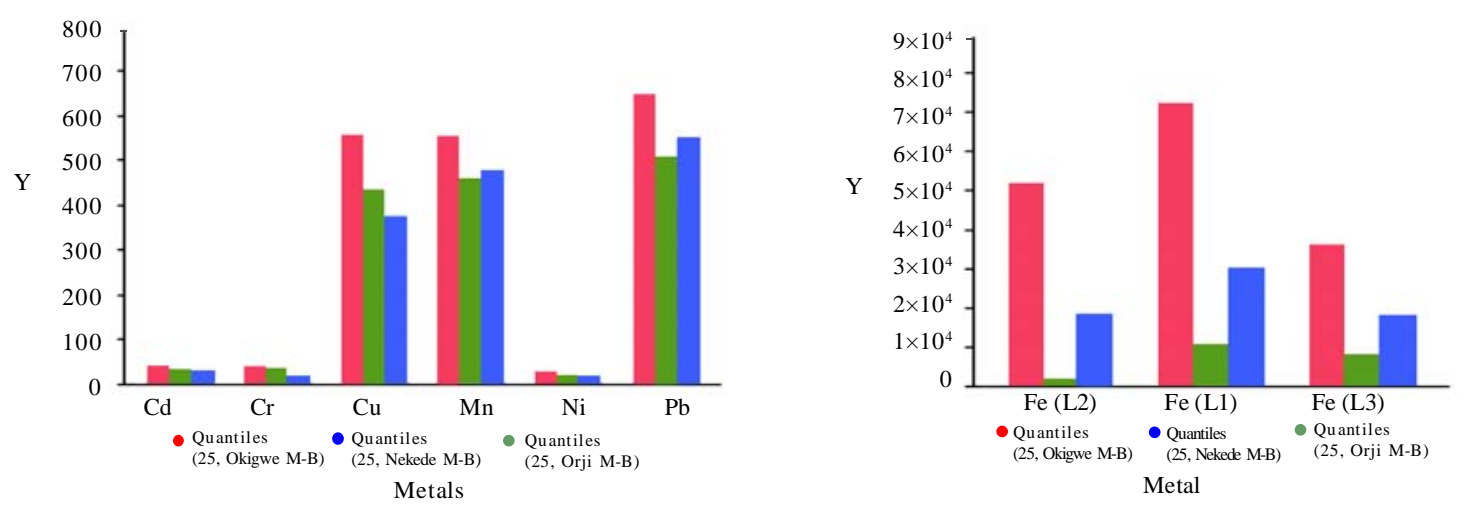

Fig. 7: $25 \%$ quantile plot of metal enrichment above background levels (M-B) in the $100 \mathrm{~cm}$ soil profile for each mechanic village

of greater concerns. Fe is not included in analysis due to its excessive background value that could submerge other values. The disparity in abundance can be attributed to a number of factors such as: a) characteristics of the topsoil; b) number of years the mechanic village has been used; c) drainage area or size of the mechanics active area; d) the degree of activity, which accounts for the operational or the workshops density, reflecting on the volume of waste generation. The mechanic villages handle all classes of motor vehicles; thus, waste generation and the resultant soil pollution varies from sections to section and suspected to be greater at locations where bigger trucks are handled. This will be investigated in future research. The order of abundance of the investigated heavy metals causing soil pollution of greater concerns within and around the mechanic villages is as follows: $\mathrm{Fe}>\mathrm{Pb}>\mathrm{Mn}>\mathrm{Cu}>\mathrm{Cd}>\mathrm{Cr}>\mathrm{Ni}$. The enrichment similarity between Orji and the Nekede mechanic villages, suggests the existence of similar soil characteristics in the two sites. Metal abundance in the $100 \mathrm{~cm}$ soil profile of the three mechanic villages (Table 1), shows similar trend of heavy metal enrichment in the 3 layers of the three mechanic villages, with exactly the same order of abundance occurring in the 0-10 and 10-20 cm layers of Okigwe and 10-20 cm layer of Nekede and Orji (Table 2)

\section{Result of physical analysis}

The infiltration rate at Okigwe varied greatly beginning at $38.1 \mathrm{~cm} / \mathrm{h}$ and ending at $2.2 \mathrm{~cm} / \mathrm{h}$. The total depth of water was $12.7 \mathrm{~cm}$ in $2 \mathrm{~h}$ and $14 \mathrm{~min}$, giving an average rate of $5.7 \mathrm{~cm} / \mathrm{h}$. At Orji, the infiltration rate varied from 25.4 to $15.24 \mathrm{~cm} / \mathrm{h}$, for an average rate of $18 \mathrm{~cm} / \mathrm{h}$. Okigwe topsoil has a higher initial infiltration rate than Orji topsoil, but becomes impermeable in about $3 \mathrm{~h}$ as its moisture content increases. The topsoil of Okigwe mechanic village consists of abundant gravel and pebbles that causes high initial infiltration rate, despite the high clay/silt content (47 \% - $64 \%)$ as 
shown in Table 3 . The pebbly and silty-clay ferruginized topsoil of Okigwe mechanic village located in the shaly zone of the basin (Fig. 1c) has wide distribution of particles ranging from $0.15 \mathrm{~mm}$ to 5.6 mm. Median diameter (Õ) of grains is 10.1 in the $0-20$ cm layer and 7.9 in the $20-100 \mathrm{~cm}$ layer, that causes the high initial infiltration rate in the Okigwe mechanic village soil. The Orji and Nekede mechanic villages located in the sandy zone, consists of fine to medium coastal plain sand (Fig. 1c), with grain sizes ranging from $0.3 \mathrm{~mm}-0.85 \mathrm{~mm}$ and predominant in the range of $0.425 \mathrm{~mm}$ - $0.6 \mathrm{~mm}$. Orji mechanic village soil has median diameter (Õ) of $5.9 \mathrm{~mm}$ in the $0-20 \mathrm{~cm}$ layer and 10.35 $\mathrm{mm}$ in the $20-100 \mathrm{~cm}$ layer, while the Nekede mechanic village has $\tilde{O}=13.45$ in the $0-20 \mathrm{~cm}$ and $\tilde{O}=12.95$ in the 20-100 cm layer (Table 4). Figs. 8a and b reveal that the mechanic villages have similar $\mathrm{pH}$ and moisture ranges under which all other measurements were conducted. The Orji topsoil has a mean $\mathrm{pH}$ of 5.75 and a moisture range of $20 \%$ - $70 \%$; the Okigwe topsoil has a mean $\mathrm{pH}$ of 6 and a moisture range of $7 \%-75 \%$. As the moisture content increases, the Okigwe mechanic village soil swells, dropping the infiltration rate to a near impermeable state (about $2 \mathrm{~cm} / \mathrm{h}$ within $2.25 \mathrm{~h}$ interval).

\section{Pollution assessment}

Values representing the maximum allowable limits (MAL) of heavy metals in soils vary from place to place. The values largely depend on the local or regional background and the threshold values. Some of the MALs have been established, mainly applicable to ecological development. For example, Kloke (1980), Kabata-Pendias, (1995) and Lacatusu (1998) have all discussed the principles for determining and standardizing values of the maximum allowable limits in different countries. Result of pollution classification (Table 1) shows wide ranges due particularly to the high values of $\mathrm{Pb}, \mathrm{Mn}$ and $\mathrm{Cu}$. Generally, $57 \%$ of the 21 metal tests have $P C>16$ in each of the mechanic villages. Okigwe and Orji share 9 respectively in the $P C$ range of 2.1-16, while Nekede has its 9 remaining metals between 4.1 and 16 , with only one in the range of 8.1-16. This implies that the Nekede mechanic village can be classified under severe to excessive pollution and the Okigwe and Orji mechanic villages classified

Table 2: Summary of the relative abundance of the metals in the three depth layers

\begin{tabular}{llll}
\hline Layer & Okigwe M. village & Nekede M. village & Orji M. village \\
\hline $0-10 \mathrm{~cm}$ & $\mathrm{Fe}>\mathrm{Pb}>\mathrm{Cu}>\mathrm{Mn}>\mathrm{Cd}>\mathrm{Cr}>\mathrm{Ni}$ & $\mathrm{Fe}>\mathrm{Pb}>\mathrm{Mn}>\mathrm{Cu}>\mathrm{Cd}>\mathrm{Ni}$ ? $\mathrm{Cr}$ & $\mathrm{Fe}>\mathrm{Mn}>\mathrm{Pb}>\mathrm{Cu}>\mathrm{Cd}>\mathrm{Ni}>\mathrm{Cr}$ \\
$10-20 \mathrm{~cm}$ & $\mathrm{Fe}>\mathrm{Pb}>\mathrm{Cu}>\mathrm{Mn}>\mathrm{Cd}>\mathrm{Cr}>\mathrm{Ni}$ & $* \mathrm{Fe}>\mathrm{Pb}>\mathrm{Mn}>\mathrm{Cu}>\mathrm{Cd}>\mathrm{Cr}>\mathrm{Ni}$ & $\mathrm{Fe}>\mathrm{pb}>\mathrm{Mn}>\mathrm{Cu}>\mathrm{Cd}>\mathrm{Cr}>\mathrm{Ni}$ \\
$90-100 \mathrm{~cm}$ & $\mathrm{Fe}>\mathrm{Mn}>\mathrm{Cu}>\mathrm{Pb}=\mathrm{Cd}>\mathrm{Cr}>\mathrm{Ni}$ & $\mathrm{Fe}>\mathrm{Mn}>\mathrm{Pb}>\mathrm{Cu}>\mathrm{Cd}>\mathrm{Cr}>\mathrm{Ni}$ & $\mathrm{Fe}>\mathrm{Mn}>\mathrm{Cu}>\mathrm{Pb}>\mathrm{Cr}>\mathrm{Cd}>\mathrm{Ni}$ \\
\hline
\end{tabular}

Table 3: Analysis of clay/slit content of soil in the three mechanic villages

\begin{tabular}{|c|c|c|c|c|c|c|}
\hline \multirow{2}{*}{$\begin{array}{l}\text { Clay/Silt Content } \\
\text { Depth }(\mathrm{cm})\end{array}$} & \multicolumn{2}{|c|}{ Orji M. Village } & \multicolumn{2}{|c|}{ Nekede M. Village } & \multicolumn{2}{|c|}{ Okigwe M. Village } \\
\hline & $0-20$ & 100 & $0-20$ & 100 & $0-20$ & 100 \\
\hline Initial sample weight before washing and drying (g) & 160.8 & 160.8 & 175.9 & 162.6 & 230.4 & 230.7 \\
\hline Sample weight after washing (g) & 128.6 & 115.4 & 141.3 & 129.6 & 122.7 & 82.9 \\
\hline Weight of fines (clay and silt) (g) & 32.2 & 45.4 & 34.6 & 33.0 & 107.8 & 147.8 \\
\hline Clay/silt content (\%) & 20.02 & 28.23 & 19.7 & 20.3 & 46.8 & 64.1 \\
\hline
\end{tabular}

Table 4: Grain size distribution in the three mechanic villages

\begin{tabular}{|c|c|c|c|c|c|c|}
\hline & \multicolumn{2}{|c|}{ Okigwe } & \multicolumn{2}{|c|}{ Nekede } & \multicolumn{2}{|c|}{ Orji } \\
\hline Sieve size & $0-20 \mathrm{~cm}$ & $20-100 \mathrm{~cm}$ & $0-20 \mathrm{~cm}$ & $20-100 \mathrm{~cm}$ & $0-20 \mathrm{~cm}$ & $20-100 \mathrm{~cm}^{2}$ \\
\hline 5.6 & 24.9 & 8.4 & 0 & 0 & 0 & 0 \\
\hline 4 & 8.3 & 5.9 & 0 & 0 & 0 & 0 \\
\hline 2 & 11.9 & 23.9 & 6 & 0.3 & 0.6 & 0 \\
\hline 1.18 & 6.6 & 10.3 & 5.2 & 8.8 & 2.5 & 2.7 \\
\hline 0.85 & 3.1 & 3.3 & 13.6 & 17.1 & 9.3 & 10.7 \\
\hline 0.6 & 20 & 7.7 & 47.3 & 53.2 & 38.6 & 46.3 \\
\hline 0.425 & 18.2 & 5.4 & 37.8 & 22.1 & 41.6 & 22.5 \\
\hline 0.3 & 7.6 & 8.1 & 13.8 & 19.6 & 9.7 & 12.3 \\
\hline 0.15 & 9.2 & 6.5 & 13.3 & 7 & 1.1 & 10 \\
\hline 0.0625 & 2.2 & 2.1 & 3.1 & 0.8 & 2 & 2.3 \\
\hline Median wt. (g) \% & 10.1 & 7.9 & 13.45 & 12.95 & 5.9 & 10.35 \\
\hline
\end{tabular}




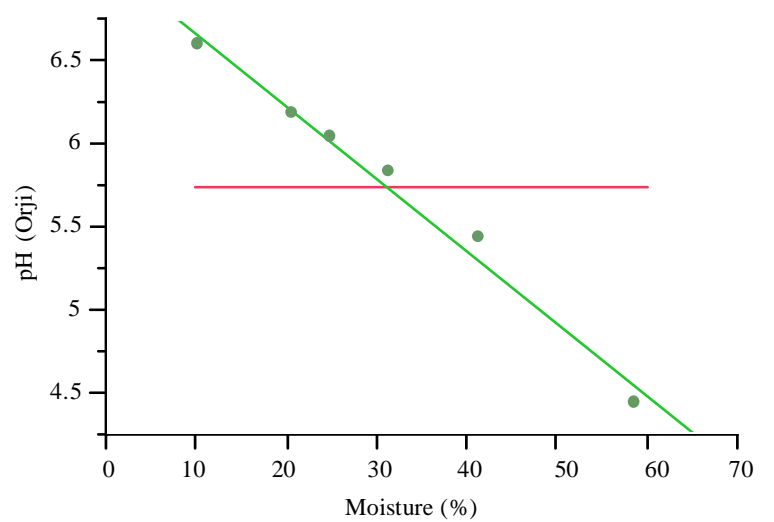

Fig. 8a: Graph of pH against moisture Orji

under moderate to excessive pollution based on the metals investigated. This result implies danger to the downstream portion of the Otamiri River at the bank of which the Nekede mechanic village is situated. Fig. 9 illustrates the degree of metal enrichment of soil above the background values in the three layers of the 100 $\mathrm{cm}$ soil profile investigated in each of the three mechanic villages. This analysis show spatial ranges of pollution indices down the profile. Okigwe mechanic village shows a decreasing trend of maximum values down the profile (top-down) and a slightly increasing trend of minimum values up the profile (bottom-up). Nekede mechanic village has a decreasing and increasing trends (mix trend) in both minimum and the maximum $\mathrm{Pi}$ ranges while the Orji mechanic village has an increasing trend (bottom-up) in the maximum $\mathrm{Pi}$ range and a decreasing and increasing trend with the minimum $\mathrm{Pi}$ range, based on the Pi values (Table 5). The decreasing trend of Pi values in the Okigwe mechanic village implies reduction in metal concentration with soil depth. It is expected that bioavailability phases of the metals, including exchangeable-carbonate bound, reducible and oxidizable phases in the shaly Okigwe soil will be greater than the coastal plain sand Nekede and the Orji mechanic villages' soil. The silty-clay characteristics (47\% - 64\%) of the Okigwe mechanic village soil (Table 3) will enhance changes in soil electrode potentials and redox reactions. This will influence the release and retention of elements in all the prevailing phases (Charlatechka and Cambier, 2000). The pebbly nature of the Okigwe mechanic village topsoil (16 \% - $30 \%$ pebble) against $0 \%$ pebble in Orji and Nekede mechanic villages is responsible for the high initial infiltration rate at Okigwe. The high concentration of $\mathrm{Pb}$ observed in the three mechanic villages can be

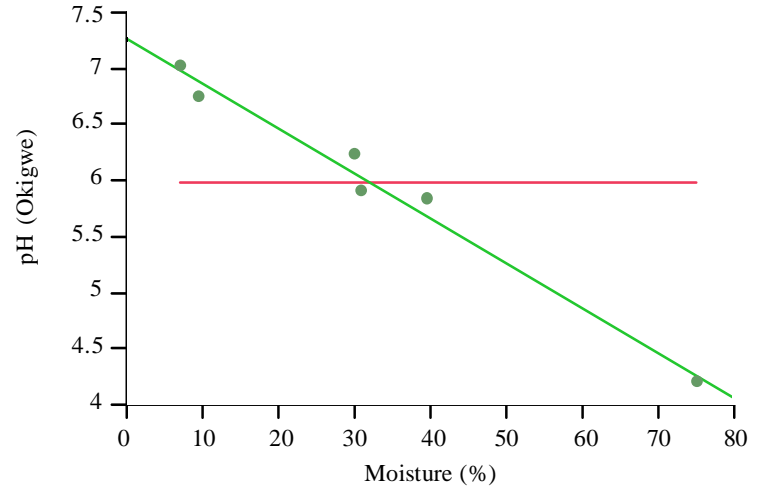

Fig. 8b: Graph of $\mathrm{pH}$ against moisture Okigwe

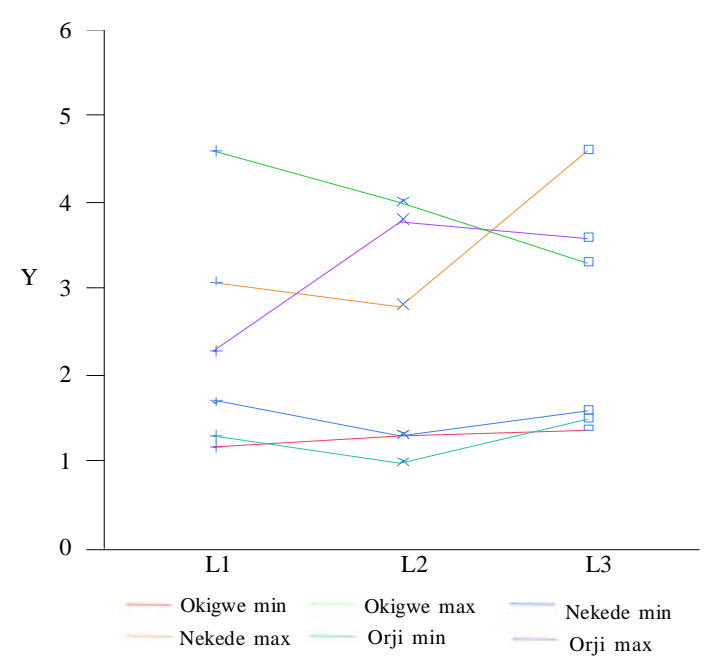

Fig. 9: Minimum and maximum ranges of pollution indices in the three soil layers

attributed to frequent and erratic emissions from automobile exhausts in all the workshops; a common practice in the MVs particularly after each engine recycling. Gasoline used in Nigeria are from several sources (local and imported), so that the methylcyclopentadienyl manganese tricarbonyl (MMT) in gasoline is not ruled out. MMT breaks down quickly in the car engine into compounds of the metal $\mathrm{Mn}$. Colmenares et al., (2000) have shown that respirable size particulates with a mass median aerodynamic diameter of $2.5 \mu \mathrm{m}$ or less $\left(\mathrm{PM}_{2.5}\right)$ in vehicle exhaust contain manganese primarily in the form of a manganese phosphate and/or sulphate. The abundance of $\mathrm{Cu}$ is also well understood, this is due to the wide use of copper and its alloys particularly in auto-electrical parts. 
Sabah, et al., 2003 used regression analysis to develop a number of predictor models for corrosion based on metal types, their location, number of months of exposure to the outside environment and the number of degrading pollutants in the air. They found that $\mathrm{Cu}$ and Fe were the most corrosive. This implies that automobile body scraps that litter, or dumped, and the unserviceable (junk) vehicles abandoned for years in the mechanic villages pollute the soil. High acidity (mean 5.75 for Orji and Nekede MVs and 6.0 for Okigwe $\mathrm{MV}$ ) thus enhance metal corrosion because heavy metal solubility is strongly dependent on soil acidity. Shuman (1995) observed that the addition of NTA (nitrilotriacetic acid) in his experiment place $\mathrm{Zn}$ and $\mathrm{Pb}$ in potentially mobile forms.

\section{CONCLUSION}

The three parameters used in this assessment: $P i$ (per metal), Pf and PC all show that the Okigwe and Nekede mechanic villages share similar degree of pollution than the Orji mechanic village. The degree of mechanic activity or population of mechanics and their workshop density affects the degree of metal enrichment in the mechanic village soil. Orji mechanic village has the largest slope and drainage area, with less workshop density, which supports wider dispersion of metal contaminants from the mechanic village, thereby reducing metal concentration in the soil. Uncontrolled spilling of waste oil on the ground must come to an end, following the introduction of extended producer responsibility (EPR). There is need for trace metal speciation and bioavailability studies within and around the mechanic villages, also to assess the lateral extent of the pollution.

\section{Environmentally friendly automobile mechanic village concept}

Environmentally friendly automobile mechanic village concept implies that EPR can be established for the disposal or otherwise recycling of used motor oil, a process that can be structured with the major petroleum marketers, whereby gas stations could periodically collect all used oil stored in mechanic villages and the mechanics are obliged to store the used oil in plastic barrels rather than the present attitude of spilling on the ground. Waste oil EPR is to be enforced under a government regulation which demands urgent consideration. The poor infrastructural development common in all the mechanic villages such as the lack of concrete floor workshops and tarred roads, lack of toilet and emission testing facilities, lack of engineered drainage system and storm water management facilities calls for immediate action of redevelopment and soil remediation in the mechanic villages. Mechanic villages properly planned and mechanics are to operate under a defined code of practice. Continuous education and training should be provided to the mechanics, emphasizing on the environmental implications of their poor occupational waste management. Code of practice and specific regulations guiding the establishment and the operation of mechanic villages must be in place and accordingly enforced. The ecological and public health implications of severe to excessive pollution of $\mathrm{Fe}, \mathrm{Pb}, \mathrm{Cu}, \mathrm{Mn}, \mathrm{Cr}, \mathrm{Ni}$ and $\mathrm{Cd}$, in the soil, at the various levels measured only after 25-30 years of the mechanic village practice are enormous. If the mechanic village concept is to be practiced based on its numerous advantages, the practice must be environmentally friendly. A comprehensive waste management plan for mechanic villages need to be established. Efficient and affordable soil remediation program by phytoremediation using local plants (Agunbiade and Fawale, 2009) and installation of groundwater quality monitoring wells in the direction of drainage are recommended in each mechanic village. Distance of wells from the mechanic villages will depend on the proximity of human residence and shallow domestic water wells to the mechanic village. Monitoring wells will enhance research on groundwater chemistry and pollution. Toxicity

Table 5: Summary of pollution assessment

\begin{tabular}{llll}
\hline Soil profile $(0-100 \mathrm{~cm})$ & Pi - Okigwe M. village & Pi - Nekede M. village & Pi - Orji M. village \\
\hline$P i$ & L1: $1.2-4.6$ & L1: $1.7-3.1$ & L1: $1.3-2.3$ \\
& L2: $1.3-4.0$ & L2: $1.3-2.8$ & L2: $1-3.8$ \\
& L3: $1.4-3.3$ & L3: $1.6-4.6$ & L3: $1.5-3.6$ \\
$P f$ & 0.8 or $80 \%$ & 0.7 or $70 \%$ & 0.5 or $50 \%$ \\
Pollution classification $(P c)$ & Severe to excessive (95\%) & Severe to excessive (95\%) & Moderate to excessive (85\%) \\
\hline
\end{tabular}

${ }^{*} \mathrm{~L} 1=0-10 \mathrm{~cm}$ layer; ${ }^{*} \mathrm{~L} 2=10-20 \mathrm{~cm}$ layer and ${ }^{*} \mathrm{~L} 3=90-100 \mathrm{~cm}$ layer 
assessment of farm products, obtained around the mechanic villages, bioavailability studies for $\mathrm{Pb}, \mathrm{Mn}$ and $\mathrm{Cu}$, analytical assessment of metal dispersion up to $400 \mathrm{~m}$ from MVs and study of local plants for phytoremediation of $\mathrm{Pb}, \mathrm{Mn}$ and $\mathrm{Cu}$ within and around MVs are strongly recommended in future research, to improve the environment and the quality of life in the basin.

\section{ACKNOWLEDGEMENTS}

The authors would thank GEOPROBE International Consultants Limited Owerri for instrumentation and logistics support that enabled this research. Also, all the supports of the Federal University of Technology Owerri, Nigeria for providing access to its soil erosion laboratory and the Federal Ministry of Science and Technology for their Atomic absorption spectrophotometer (AAS) equipped laboratory at Uyo would be appreciated. Special thanks go to the staff of GEOPROBE for participation in the field work.

\section{REFERENCES}

Agunbiade, F. O.; Fawale, A. T., (2009). Use of Siam weed biomarker in assessing heavy metal contaminations in traffic and solid waste polluted areas. Int. J. Environ. Sci. Tech., 6 (2), 267-276 (10 pages).

Aina, M.; Matejka, G.; Mama, D.; Yao, B.; Moudachirou, M., (2009). Characterization of stabilized waste: Evaluation of pollution risk. Int. J. Environ. Sci. Tech., 6 (1), 159-165 (7 pages).

ASTM D3385-09, (2009). Standard test method for infiltration rate of soils in field using double-ring infiltrometer. ASTM International.

Barabara, F.; Stephen, K.; William, W., (2002). Speciation and character of heavy metals contaminate soil using computercontrolled scan electron microscope. Environ. Forensic, 3 (2), 131-143 (13 pages).

Charlatchka, R.; Cambier, P., (2000). Influence of reducing conditions on solubility of trace metals in contaminated soils. Water Air Soil Pollut., 118 (1-2), 143-168 (26 pages).

Chee, Poh, S.; Tahir, N. M.; Zuchi, H. M.; Musa, M. I.; Hork Ng., K.; Noor, A. M., (2006). Heavy metal content in soil of major towns in the east coast of peninsular Malaysia. Chinese J. Geoch., 25 (S1), 56.

Colmenares, C.; Deutsch, S.; Evans, C.; Nelson, A. J.; Terminello, L. J.; Reynolds, J. G.; Roos, J. W.; Smith, I. L., (2000). Analysis of manganese particulates from automotive decomposition of methylcyclopentadienyl manganese tricarbonyl. Appl. Surf. Sci., 151 (3-4), 189-202 (14 pages).

Corbillon, M. S.; Olazabal, M. A.; Madariaga, J. M., (2008). Potentiometric study of aluminum-fluoride complex equilibria and definition of the thermodynamic model. J. Solution Chem., 37 (4), 567-579 (13 pages).

Crowder, M., (1992). Interlaboratory comparisons: Round robins with random effects. Appl. Stat., 41 (2), 409-425 (17 pages).

D’ Ascoli, R.; Rao, M. A.; Adamo, P.; Renella, G.; Landi, L.;
Rutigliano, F. A.; Terribile, F.; Gianfreda, L., (2005). Impact of river overflowing on trace element contamination of volcanic soils in south Italy: II Soil bio and biochem properties in relation to trace element speciation. Environ. Pollut., 144 (1), 317-326 (10 pages).

David, H.; Johanna, E. J., (2000). Organochlorine, heavy metal and Polyaromatic Hydrocarbon Pollutant concentrations in the Great Barrier Reef environ: A Review. Mar. Pollut. Bull., 41 (7-12), 267-278 (12 pages).

Diatta, J. B.; Kociałkowski, W. Z.; Grzebisz, W., (2003). Lead and zinc partition coefficients of selected soils evaluated by Langmuir, F., and linear isotherms. Comm. Soil Sci. Plant Anal., 34 (17-18), 2419-2439 (21 pages).

Dioka, C. E.; Orisakwe, O. E.; Adeniyi, F. A.; Meludu, S. C., (2004). Liver and renal function tests in artisans occupationally exposed to lead in mechanic village in Nnewi, Nigeria. Int. J. Environ. Res. Pub. Health, 1 (1), 21-25 (5 pages).

Ergin, M.; Saydam, C.; Basturk, O.; Erdem, E.; Yoruk, R., (1991). Heavy metal concentration in surface sediments from the two coastal inlets (Golden horn estuary and Izmit bay of the northeastern sea of Marmara. Chem. Geol., 91 (3), 269-285 (17 pages).

Feng, H.; Cochran, J. K.; Lwiza, H.; Brownawell, B.; Hirschberg, D. J., (1998). Distribution of heavy metals and PCB contaminants in the sediments of an urban estuary of the Hudson River. Mar. Environ. Res., 45 (1), 69-88 (20 pages).

Feng, H.; Han, X.; Zhang, W.; Yu, L., (2004). A preliminary study of heavy metal contamination in Yangtze River intertidal zone due to urbanization. Mar. Poll. Bull., 49 (1112), 910-915 (6 pages).

Feng, X. D; Dang, Z; Huang, W. L; Yang, C., (2009). Chemical speciation of fine particle bound trace metals. Int. J. Environ. Sci. Tech., 6 (3), 337-346 (10 pages).

Han, Y. M; Du, P. X; Cao, J. J; Posmenteir, E. S. (2006). Multivariate analysis of heavy metal contamination in urban dusts of Xian central China. Sci. Total Environ., 355 (1-3), 176-186 (11 pages).

Huang, X.; Sillanpää, M. Gjessing, E. T. Vogt, R. D., (2009). Water quality in the Tibetan Plateau: Major ions and trace elements in four major Asian rivers. Sci. Total Environ., 407 (24), 6242-6254 (13 pages).

Huang, X.; Sillanpää, M.; Duo, B.; Gjessing, E. T., (2008). Water quality in the Tibetan Plateau: Metal contents of four selected rivers. Environ. Pollut., 156 (2), 270-277 (8 pages).

Igbozuruike, C. W. I.; Opara-Nadi, A. O.; Okorie, I. K., (2009). Concentrations of Heavy metals in soil and cassava plant on sewage sludge dump; UC Davis, the Proceedings of the International Plant Nutrition Colloquium XVI, International Plant Nutrition Colloquium.

Ivanova, E.; Stoimenova, M.; Gentcheva, G., (1994). Flame AAS determination of $\mathrm{Cd}$, As and $\mathrm{Ti}$ in soil and sediments after their simultaneous carbodithiate extraction. Frensen. J. Anal. Chem., 348 (4), 317-319 (3 pages).

Ipeaiyeda, A. R.; Dawodu, M., (2008). Heavy metals contamination of topsoil and dispersion in the vicinities of reclaimed auto-repair workshops in Iwo Nigeria. Bull. Chem. Soc. Ethiopia, 22 (3), 339-348 (10 pages).

Iwegbue, C. M., (2007). Metal fractionation in soil profiles at 
automobile mechanic waste dumps around Port- Harcourt. Waste Manage. Res., 25 (6), 585-593 (9 pages).

Kabata-Pendias, A., (1995). Agricultural Problems Related to Excessive Trace Metal Contents of Soil, in "Heavy Metals (Problems and Solutions)”, (Ed. W. Salomons, U. Förstner and P. Mader), Springer Verlag, Berlin, Heidelberg, New York, London, Tokyo, 3-18.

Karbassi, A. R., Monavari, S. M., Nabi Bidhendi, G. R., Nouri, J., Nematpour, N., (2008). Metal pollution assessment of sediment and water in the Shur River. Environ. Monit. Assess., 147 (1-3) 107-116 (10 pages).

Kloke, A., (1980). Richwerte '80, Orientierungsdaten für tolerierbare Gesamtgehalte einiger Elemente in Kulturböden, Mitt. VDLUFA, H. 2, 9-11.

Lacatusu, R., (1998). Appraising levels of soil contamination and pollution with heavy metals, Developments for planning and sustainable use of land resources published by European Soil Bureau joint research center, 393-402 (10 pages).

Liu, C.; Zhang, Y.; Zhang, F.; Zhang, S.; Yin, M.; Ye, H.; Hou, H.; Dong, H.; Zhang, M.; Jiang, J.; Pei, L., (2007). Assessing pollutions of soil and plant by municipal waste dump. Environ. Geol., 52 (4), 641-651 (11 pages).

Mandel, J., (1991). Evaluation and control of measurements. Quality and reliability series Dekker publication.

Mohiuddin, K. M.; Zakir, H. M.; Otomo, K.; Sharmin, S.; Shikazono, N., (2010). Geochem distribution of trace metal pollutants in water and sediments of downstream of an urban river. Int. J. Environ. Sci. Tech., 7 (1), 17-28 (12 pages).

Murray, V. G.; Hendershot, W. H., (2000). Trace metal speciation and bioavailability in urban soils. Environ. Pollut., 107 (1), 137-144 (8 pages).

Nuga, B. O.; Akinbola, G. E.; Lawal, O.; Gaiser, T.; Herrmann, L., (2006). Production of the 1:350000 scale digital geologic map of the old Imo state. Electron. J. Environ. Agri. Food Chem., 5 (6), 1654-1658 (5 pages).

Nwuche, C. O.; Ugoji, E. O., (2008). Effects of heavy metal pollution on the soil microbial activity. Int. J. Environ. Sci. Tech., 5 (3), 409-414 (6 pages).

Onianwa, P. C.; Jaiyeola, O. M.; Egekenze, R. N., (2001). Heavy metal contamination of topsoil in the vicinities of auto-repair workshops, gas stations and motor parks in a Nigerian city Toxicol. Environ. Chem., 84 (1-4), 33-39 (7 pages).

Onweremadu, E. U.; Doruigbo, C. I., (2007). Assessment of Cd concentration of crude oil arable soil. Int. J. Environ. Sci. Tech., 4 (3), 409-412 (4 pages)
Onyeagocha, A. C., (1980). Petrography and Depositional Environment of the Benin Formation, Nigeria. J. Mining Geol., 17, 147-151 (5 pages).

Pardo, M. T., (2002). Sorption of lead, copper, zinc and cadmium by soils, effects of nitriloacetic acid on metal retention. Soil Sci. plant Anal., 31 (1-2), 31-40 (10 pages).

Remon, E.; Bouchardon., J. L.; Cornier, B.; Guy, B.; Leclerc, J. C.; Faure, O., (2005). Soil characteristics, heavy metal availability and vegetation recovery at a former metallurgical landfill: Implications in risk assessment and site restoration. Environ. Pollut. 137 (2), 316-323 (8 pages).

Rukhin, R. L.; Mark, G. V., (1998). Estimation of a common mean and weighted means: Statistics. J. Am. Stat. Assoc., 93 (441), 303-308 (6 pages).

Sabah, A. A.; Bakheit, C. S.; Siddigui, R. A.; Al-Alawi, S. M., (2003). Atmospheric corrosion of metals. J. Corrosion Sci. Eng., 5.

Shuman, L. M., (1995). Effects of nitrilotriacetic acid on metal adsorption isotherms for two soils. Soil Sci., 160 (2), 92-100 (9 pages).

Sorvari, J.; Sillanpää, M., (1996). Influence of metal complex formation on heavy metal and free EDTA and DTPA acute toxicity determined by D. Magna. Chemosphere, 33 (6), 11191127 (9 pages)

Tam, N. F. Y.; Wong, Y. S., (2000). Spatial variation of heavy metals in surface sediments of Hong Kong mangrove swamps. Environ. Pollut., 100 (2) 195-205 (11 pages).

Virkutyte, J.; Sillanpää, M., (2006). Chemical Evaluation of Potable Water in Eastern Qinghai Province, China. Hum Health Aspects Environ. Int., 32 (1), 80-86 (7 pages).

Ximming, W.; Genxing, P.; Ping, C., (2005). The distribution and speciation of heavy metals in urban soils in Nanjing City: In Urban Dimensions of Environmental Change, Science Press USA Inc., 25-33.

Yuan, C. J.; Shi, B.; He, J.; Liu, L.; Jiang, G., (2004). Speciation of heavy metals in marine sediments from the East China sea by ICP-MS with sequencial extraction. Environ. Int., 30 (6), 769783 (15 pages)

Zhang, L.; Ye, X.; Feng, H.; Jing, Y.; Ouyang, T.; Yu, X.; Liang, R.; Chen, W., (2007). Heavy metal contamination in the $\mathrm{W}$ Xiamen bay sediments and its vicinity China. Mar. Pollut. Bull., 54 (7), 974-982 (9 pages).

Zhang, W.; Feng, H.; Chang, J.; Jianguo, Q.; Hongxia, X.; Lizhong, Y.; (2009). Heavy metal contamination in surface sediments of Yantze intertidal zone: An assessment from different indexes. Environ. Pollut., 157 (5), 1533-1543 (11 pages).

\section{AUTHOR (S) BIOSKETCHES}

Nwachukwu, M. A., Ph.D. Candidate, Department of Earth and Environmental Studies, School of Science and Mathematics, Montclair State University New Jersey U.S.A. Email: nwachukwum1@mail.montclair.edu

Feng, H., Ph.D., Full Professor, Department of Earth and Environmental Studies, School of Science and Mathematics, Montclair State University New Jersey USA. Email: fengh@mail.montclair.edu

Alinnor, J., Ph.D., Associate Professor, Department of Chemistry, Federal University of Technology Owerri, Nigeria.

Email: alijuiyke@yahoo.com

How to cite this article: (Harvard style)

Nwachukwu, M. A.; Feng, H.; Alinnor, J., (2010). Assessment of heavy metal pollution in soil and their implications within and around mechanic villages. Int. J. Environ. Sci. Tech., 7 (2), 347-358. 